\title{
Disability and the implication of coaccessibility: a case study on accessibility to the media in Turkey
}

2020, Vol. 42(6) 987-1002

(C) The Author(s) 2020

Article reuse guidelines: sagepub.com/journals-permissions DOI: 10.1 I77/0I63443720908I33 journals.sagepub.com/home/mcs

\section{A Şirin Okyayuz (i)}

Bilkent University, Turkey

\section{Mümtaz Kaya}

Hacettepe Universitesi Edebiyat Fakultesi, Turkey

\begin{abstract}
Media accessibility has been an important issue on the international agenda since the early 2 I st century. Many countries have achieved major developments in media accessibility, while others like Turkey are currently embarking on the journey. The following article discusses developments in media accessibility in Turkey with emphasis on disability and the implication of coaccessibility which may be defined broadly as appealing to audiences with differing accessibility needs, through the translation(s) inputted on a single product. The research so far seems to indicate that coaccessibility has potential political, social, educational and other implications. Turkish end-users embrace the current coaccessibility model, but the ultimate goal in accessibility for Turkey is to have optional sign language interpreting, audio description and subtitling for the D/deaf and hard of hearing and the actors need to strive to achieve this. Currently, it also falls to academics to research this phenomenon of coaccessibility, learn from it, both in terms of the practice itself and its possible implications for universal design, and design for all, and to ensure that end-users and others benefit from it until the day it can be replaced with a better option.
\end{abstract}

\section{Keywords}

audio description, audiovisual translation, coaccessibility, disability, media accessibility, sign language interpreting, subtitling for the D/deaf and hard of hearing

\footnotetext{
Corresponding author:

A Şirin Okyayuz, Bilkent University, 06800 Ankara, Turkey.

Email: yener@bilkent.edu.tr
} 


\section{Introduction: media accessibility in the $\mathbf{2}$ I st century}

Media accessibility (MA), broadly defined for the scope of this article, is accessibility to media services and programmes through the use of various, both interlingual and intralingual, modes of translation (i.e. subtitling for the D/deaf and Hard of Hearing (SDH), audio description (AD), live subtitling, sign language interpreting (SLI) of audiovisuals) designed to meet the needs of audiences with visual, hearing and other impairments. Since new media plays a significant role in civic life and education (see Ellis and Kent, 2011) and there is an increasing awareness on the crucial role of MA, the discussion of disability in both media and translation studies becomes essential. Lazar and Stein (2017: 1-8) stress the global issue of equal access to information and communications technology (ICT) by persons with disabilities. The right to access ICT and MA invokes complementary civil and human rights issues.

Accessibility became an important issue on the international agenda in the early $21 \mathrm{st}$ century. Multiple factors such as the efforts of non-governmental organization's (NGO) increase in societal awareness concerning persons with disabilities and their needs, the developments in technology facilitating MA, work and research in various fields of expertise related to the issue and many others contributed to this development.

One of the factors that led impetus to the development was the Convention on the Rights of Persons with Disabilities (CRPD) (2006) and its Optional Protocol (A/RES/61/106) of the United Nations. Article 9 of the CRPD (2006) states the following:

To enable persons with disabilities to live independently and participate fully in all aspects of life, States Parties shall take appropriate measures to ensure to persons with disabilities access, on an equal basis with others, to the physical environment, to transportation, to information and communications, including information and communications technologies and systems, and to other facilities and services open or provided to the public, both in urban and in rural areas.

This imperative entails mainstreaming accessibility in all digital products, contents, environments and services.

Following this impetus, each signatory country started varied initiatives to provide accessible media services. Initiatives were led at a pace designated by the realities of the country in question. Many, especially Western countries, have come a long way in supporting MA for the disabled. Not only have SDH, AD and SLI become mainstream practices, but projects, seminars and the like have increased, supporting new and innovative translation methods and tools, standardization, innovative technologies and multiple platforms of research required for the advancement of the field.

The Republic of Turkey signed the UN Convention on 30 March 2007 (see Resmi Gazete, 2009). After the ratification of the Convention, MA became a major issue on the governmental, political and social agenda in Turkey. State organs initiated projects, academic interest in the subject increased and other developments ensued.

\section{Developments in media accessibility in Turkey}

In Europe, following the Audiovisual Media Services Directive (AVMSD) (2018), all countries have the obligation to pass legislation regarding accessibility services offered in public broadcasting (Matamala and Orero, 2018: 142-143). Since there is no European 
Union standard for SDH, SLI or AD, the AVMSD could only measure the quantity of programmes to be broadcasted with each service. Each European Union (EU) country has its own standardization agency to set, reflect and monitor national and international standards in the provision of MA. Each country also has its own independent media regulating body under the European Regulators Group for Audiovisual Media Service (ERGA, 2014). The latter is responsible for advising the Commission on the implementation of AVMSD.

As with other countries, one of the major stakeholders in such initiatives is the media regulator body in Turkey. The Turkish Radio and Television Supreme Council (RTÜK) monitors and regulates all media activity in Turkey and has the political power to provide wide-scale MA.

In December 2018 - January 2019 RTÜK held a workshop for the development of accessibility to audiovisual media services. The official paper on the steps to be taken for MA was published at the final meeting on 15 January 2019 (see Radyo ve Televizyon Üst Kurulu (RTÜK), 2019).

The authorities explained the process that led to this development as follows. According to state statistics from 2002, about $13 \%$ of the population did not have access to media services. Work for MA for persons with disabilities started at RTÜK in 2007. In 2011, a special law about MA for the disabled entered into force. In 2014, the amended internal legislation on media referred to a requirement on minimum hours of accessibility on television channels and platforms. So far the developments were only on paper. Due to difficulties in the implementation of services, RTÜK decided to hold a workshop between the 2016 and 2020 strategic planning period for the development of MA services (RTÜK, 2019: 3-7).

The workshop hosted over 50 participants from NGOs, government organs, television channels and media platforms, technical experts and academics researching the field (RTÜK, 2019: 18-39). The workshop was a success in the sense that a guideline was developed and actors agreed that MA was a priority.

The guideline states that $\mathrm{AD}, \mathrm{SLI}$ and $\mathrm{SDH}$ are to be encouraged on state channels for news, shows, films and series (from 7:30 a.m. to 12:00 p.m. and especially for prime time). These are to be produced (with a certain time lag) at certain standards by accredited individuals and edited by end-user editors. The initial output of MA practices will increase regularly (RTÜK, 2019: 42-49).

The Declaration has been adopted as the Directive on the Procedures and Principles Regarding the Development and Improvement of Accessibility to Media Providers Services for the D/deaf, Hard of Hearing and Visually Impaired on 11 October 2019 and published in the Official Gazette (Resmi Gazete, 2019).

In practice, the quantity and quality of $\mathrm{AD}$, SLI and SDH have flourished and continue to grow through the efforts of an NGO (Sesli Betimleme Derneği (SEBEDER), 2018) and the support of public/private channels.

\section{The MA scene and coaccessibility}

Until the accessible versions of various media appear in the forms dictated by RTÜK in the near future, these are currently available as coaccessible video on demand (VOD): $\mathrm{AD}, \mathrm{SLI}$ and SDH on the same video. Thus, MA in Turkey is provided in the form of 
coaccessibility. Coaccessibility (a term coined by authors removed in the 2019 RTÜK workshop and cited in the terminology section of the ensuing declaration) may be defined broadly as appealing to audiences with differing accessibility needs, through the translation(s) inputted on a single product not initially designed for access for all.

There are obvious downsides to coaccessibility such as information overload until the human ear gets used to multiple inputs (i.e. the original soundtrack and the AD), and information overload on screens (i.e. the SLI on the bottom right and the SDH centred at the bottom of the screen). Considering the fact that the blind do not access the visual presentations of subtitles and SLI, and the fact that the D/deaf and hard of hearing do not access the audial channel, in terms of end-user reception, there is no down side to having these modes of translation on the same product.

Coaccessibility has different facets, such as appealing to different users of similar translation types (i.e. the use of subtitles by both the D/deaf and the hard of hearing $(\mathrm{HoH})$, or the use of different types of translation to access a single product (i.e. the use of $\mathrm{AD}$ and $\mathrm{SDH}$ for persons with both hearing and visual impairments). It also provides the option of allowing disabled (i.e. hearing or visually impaired) and other end-users of translation proper (such as dubbing) to watch a product together.

\section{Coaccessibility: political, educational and social implications}

Accessibility supported by state initiatives and NGO's in most developed countries is usually provided as an option, with closed and open captions/subtitles and an additional audial channel that may be added on through the TV remote or other controls for AD. Researchers and others would agree that the important point is to provide accessibility and increase quantity and quality (see Media for All, 2019; Understanding Quality in Media Accessibility (UMAQ), 2018).

Why would Turkey be considering or trying to map the implications of coaccessibility at a time when many countries have already been able to provide optional use of MA? In order to answer this question we would need to look at the country in which such a practice is implemented, weigh its realities and then make both a short-term and long-term assessment about the issue.

The following section provides an overview of the present day Turkish setting from a political, educational and social standpoint.

\section{Political implications}

Coaccessibility implies (in essence) that groups of people who require different modes of translation to access an audiovisual product work together politically. It should be underlined that at this juncture, the word 'political' is taken to mean 'for the implementation of governmental and public policy'. A joint effort would be fundamental to success in getting the quantity and quality of MA required. The reason is simple: there is always political strength in numbers.

In the Turkish case, with a history of elections with slight margin wins, votes matter. The chance of achieving policy change is always higher when there are a large number 
of people petitioning for something. Research by the State Statistics Institute (DİE ve Başbakanlık Özürlüler İdaresi Başkanlığ 1 , 2002) has revealed that the disabled form approximately $12.29 \%$ of the population, meaning that there are approximately $8,431,937$ disabled persons in Turkey. The last comprehensive research on the subject in 2001 revealed that approximately one out of every nine citizens has a disability (Öztürk, 2011: 9). It is clear that any initiative embarked upon with the joint force of the large number of people involved will resonate on the political platform.

On the other hand, in the 21 st century Turkey, it is still not possible to state that there is large-scale awareness on disability. One researcher comments that though compared with previous centuries the conditions of the disabled have improved, today the disabled in Turkey still live in the confines of their homes isolated from the society and the reality that surrounds them. The number of initiatives undertaken have not fully alleviated the problems surrounding the disabled, many of whom according to social researchers are still undereducated, in many cases illiterate, unemployed, without social security and poor (Öztürk, 2011: 16-17).

In countries like Turkey where there is a lack of large-scale awareness on disability, the way society views individuals with disabilities is also an important concern. For example, a blind person has a disability which is clearly noted by the others (i.e. given away by the person's inability to navigate their surroundings with the same ease as others). Whereas in the case of a $\mathrm{D} /$ deaf or $\mathrm{HoH}$ individual, this is not the case until they try to communicate with others. The $\mathrm{D} /$ deaf and $\mathrm{HoH}$ community in Turkey refer to themselves as being 'the invisible disabled'. In the example Turkey presents of a relatively more conservative, developing nation, the inability to communicate is also unfortunately associated with a lack of knowledge, and in some rare cases even intelligence (for examples of research reaffirming the existence of and countering this misconception in Turkey in terms of education, see Doğan, 2015; Soysal et al., 2001). Due to the fact that the average person, the civil servant and politician (who are in a position to provide or promote accessibility) do not share the same culture and language with the disabled in question, the D/deaf are generally not very good at 'making their voices heard'. During the RTÜK meetings in 2018-2019, the Associations for these individuals stated that working together with the blind community has allowed them to advance politically in a way that would not have been possible on their own.

To explain the need for unity for MA, we need to look at the realities of the disabled in the country. Historically the blind, the $\mathrm{D} /$ deaf and $\mathrm{HoH}$ have been grouped together on the Turkish political front and social life at large. For example, Donat (2011: 39-104) cites 15 official standards, 8 communiqués, 14 memorandums, 70 bylaws, 4 legislative decrees, 57 laws in which the disabled are mentioned as a group. Another example of this solidarity was the establishment of special schools for the communities in question. Starting in 1889 during the Ottoman era, schools were built side-by-side with the joint use of some premises (Turgut and Taşç1, 2011). Studies on these institutions dwell on the specialized training and the importance of education for the communities in question (see Ergin, 1939; Gök, 1958; Yıldırım, 1997).

A further so-called development which is lamented by the communities in question and mentioned in the petition of Community led Associations reports to state organs (Utsukarcı and Özdemir, 2019) is the new Turkish model of primary and secondary 
training referred to as inclusive education where people with disabilities are placed in the same classrooms with other non-disabled students. This policy is supported by many nations around the world with success (see UNICEF, 2012). Unfortunately, this is not the case in Turkey because the implementation is not what it should be. This model which is designed to integrate the disabled has only led to a generation of undereducated individuals who neither speak their mother tongue (Turkish sign language (TID)) nor read and understand Turkish to the extent required for further education. With some teachers unprepared for this setting and many families at a loss to object, there are examples of the younger generation who do not have a sense of belonging strongly to one community or the other (for details of research and findings on the subject, see Akmeşe, 2016; Parlak, 2011; Sarıkaya and Börekçi, 2016; Sart et al., 2016; Uysal, 2010). Those who are above approximately 35 years of age, and who have been trained in special schools designate TID as their mother tongue and are 'limited' in terms of access to written language, whereas those approximately below 35 trained in inclusive education do not consider TID their mother tongue and do not have a good grasp of the language but unfortunately also do not have a good grasp of written Turkish due to the lack in the current implementation of the inclusive education policy.

So, whereas there are blind academics, lawyers, high-ranking civil servants and politicians in Turkey (even though the numbers are still low), such is not the case for the Deaf. The Deaf were given the opportunity to train in universities within the scope of the Accessible Universities Project initiated by the Turkish Council of Higher Education (YÖK). The issue of attending higher education and thus the increasing presence in public life, society and the workplace for the disabled to be discussed under the educational implications of coaccessibility clearly show that there are initiatives for the improvement of infrastructure. There is hope that willingness to attend higher education will increase over time.

The long and short of the matter is, as historically documented with examples in Turkish legislation, politics and other fronts, issues for the disabled require the joint force of all parties in Turkey. If it becomes an issue debated and focused on by individual groups with differing disabilities, it has been noted that one group will lag behind the other in getting results.

\section{Educational implications}

On the educational front, in order to fully comprehend the implications of coaccessibility, we would need to look at issues such as the recognition and the use of TID, primary and secondary education for the disabled, their options in higher education and their use of MA services. TID is only fully comprehended as mother tongue by a portion of the $\mathrm{D} / \mathrm{deaf}$ and $\mathrm{HoH}$ population. There are various reasons behind this. TID has not been studied as diligently as its counterparts in other parts of the world, as an overview of the developments concerning TID exemplifies. In 1983, the Turkish Ministry of Education acknowledged they did not have a reference book on TID, and how this impacted the Deaf community and they started working on creating one (Özbaykal as cited in Akalın et al., 2014: 48). In 1995, the Ministry of Education published the Sign Language Handbook for Adults. The TİD Alphabet was published 
the same year (Kobal and Şenturan, 1995). Academics began studies on TiD at the start of the millennium, concentrating on the syntax and grammar of the language. A list of all academic work on the subject is compiled in the TiD Bibliography (Arik, 2012-2015).

TID was officially recognized on 7 July 2015 when Law numbered 5378 was published in the Official Gazette. In Article 15, it is stated that TiD is formulated by the Turkish Language Association, and that work on the formulation and use of TiD is to be coordinated by the Association through a joint effort with the Ministry of Education, Social Services and Child Protection Institution, and Prime Ministry Department of the Administration for the Disabled (Akalın et al., 2014: 49). Despite the relatively recent developments, today, a rough estimate reveals that there are over three million $\mathrm{D} /$ deaf and $\mathrm{HoH}$ in Turkey, whereas only about 800,000 use TID as mother tongue and comprehend it (Firat, 2019).

School attending rates are also important considerations for MA, because they reveal facts such as the number of people within the Deaf and $\mathrm{HoH}$ communities who are literate, the extent of literacy, the use of TID which tie in with how (i.e. through the use of which mode of translation, SDH or SLI) to provide MA services. As mentioned previously under public policy, special D/deaf and blind schools have been established in Turkey since the Ottoman era. These institutions were considered successful initiatives until educational policy dictated a change in the system. To the extent possible D/deaf and blind individuals attended these (mostly boarding) schools. But, whereas, a larger portion of the blind went on to higher education because they were able to communicate in a spoken language, this was not the case for the D/deaf. Currently, blind individuals are on the average more highly educated, whereas the political infrastructure for education for the D/deaf is still being established. In 2010, in a joint survey with the Ministry of Family and Social Policy, the Turkish Statistical Institute found that, whereas $29 \%$ of the blind (and visually impaired) population attended primary school, only $17 \%$ of the D/ deaf and $\mathrm{HoH}$ were able to attend. One must also keep in mind that the spectrum for the blind is generally narrower than that for the hearing impaired with the Deaf (persons who identify with the Deaf culture and use sign language as mother tongue) forming the edge of the spectrum. Figures for Deaf and $\mathrm{HoH}$ attending higher education are also much lower (TÜİK and ASPB, 2010).

In 1985, within the scope of the Accessible Universities Project initiated by the Turkish Council of Higher Education, new rules were adopted to ensure that disabled individuals were not at a disadvantage. In 2005, work started on a new regulation for disabled university students. In 2006, universities started to establish special units to assist disabled students. The 20 June 2006 dated 26204 numbered initial Directive on the subject published in the Official Gazette has since been abolished and replaced by an amended version. In accordance with the Law on Persons with Disabilities numbered 5378 (Engelliler Hakkında Kanun, 2005), the Turkish Council of Higher Education ratified a bylaw (Yükseköğretim Kurumları Engelliler Danışma ve Koordinasyon Yönetmeliği, 2010) which was published in the 27672 numbered Official Gazette on 14 August 2010. This regulation enacted in 2010 was designed to facilitate services for disabled students continuing their higher education; this was further enlarged in 2013 (Yükseköğretim Kurulu Engelli Erişim Komisyonu, 2019). 
All of these facts tie in with MA services because of two reasons. Initially many forms of accessibility are an educational tool. For example, previous research has shown the benefits of accessibility and especially the use of subtitles for language training/education (e.g. see Beseghi, 2013; Bianchi, 2015; Caimi, 2006; Díaz-Cintas and Fernández Cruz, 2008; Mitterer and Mcqueen, 2009; Pavesi and Perego, 2008; Taylor, 2003; Vanderplank, 1988; Williams and Thorn, 2000; Zarei and Rashvand, 2011). The same is also true of the use of SLI in accessibility. Second, as will be explained under social implications, coaccessibility also provides societal education about the disabled for both non-disabled persons and also for the disabled on different parts of the similar (and/or different) disability spectrum.

A recent survey conducted on end-users of coaccessible versions of audiovisual products (Okyayuz et al., 2017) revealed very interesting findings that partially confirm the two advantages referred to above.

Individuals who use TID as mother tongue state that they benefit from the coappearance of subtitles and SLI in audiovisual products in several ways:

- They learn new words and expressions in written Turkish improving their reading skills.

- Consistent use of subtitles has positively affected their reading speed and to some extent their reading enjoyment.

- They learn new signs (words and expressions) in their mother tongue (TID).

- Several respondents from the Community feel that reading subtitles (with help from their mother tongue TID) improves their language skills to the extent that it affects their daily lives. For example, centralized state exams like the drivers licence exam can only be taken in the written mode in Turkey. Thus, the D/deaf need to read and understand the multiple choice question and expressions. Improving their linguistic abilities has facilitated success in such efforts.

Individuals who use SDH as primary access mode to audiovisual products state that they benefit from the co-appearance of SLI in several ways:

- HoH or deaf individuals feel that they learn new expressions in TiD and written and spoken Turkish.

- HoH individuals feel that they have the option of expressing themselves in another mode such as TID. They see it is widely used by others as an ideal tool for communication.

Coaccessibility also seems to provide education in the shared difficulties and solutions available for persons with similar but differing disabilities. It unites the disabled across a spectrum. For example, the Deaf are a close-knit community in Turkey and just like any close-knit community do not fully accept $\mathrm{HoH}$ individuals (individuals with cochlear implants etc.) into their ranks, since they feel these individuals who do to some extent have access to the hearing community are not really part of theirs. They are referred to as 'halves'. The use of a common language (TID) or the use of a common mode of translation (SDH) brings together end-users in the sense that they access an 
audiovisual product in the same manner. In this sense, it leads to further integration of fragmented disabled communities. For example, the $\mathrm{HoH}$ and the Deaf communities held internal debates and meetings during the 2018-2019 RTÜK process in Turkey once they understood the mutual benefit for each community concerned and collectively supported both modes of translation.

As can be concluded, coaccessibility (especially for those users on different ends of a similar disability spectrum) leads to many important developments. Coaccessibility allows for end-users to have two modes of translation to pick and choose input and learn from; in some cases, even cross-reference for further input. In addition to this there are the benefits of allowing further integration of disabled communities on different parts of the spectrum in a common struggle, through the education of the communities on the realities and possible MA solutions for all. This also ties in with universal design and design for all issues which are discussed in the conclusion of the study.

\section{Social implications}

A third facet is the social benefit of coaccessibility. This issue needs to be discussed from two differing perspectives. The first perspective entails the awareness raising potential of coaccessibility.

If versions of programmes on national channels viewed by millions contain either one or several translations, it is clear that society at large will have a better understanding of the ways in which the disabled access media. Today, whereas SDH is slightly more visible, less frequently implemented SLI and especially AD which is only available on VOD are lesser known forms of accessibility in Turkey. This limits the number of people in society who are aware of possible developments concerning MA for the disabled. Also, other potential users of MA services such as people using SLI versions to learn sign language or individuals who have age related vision or hearing loss also become aware that they have the option of using SDH or AD. In short, when more people know about a possibility and the purpose it can serve, it follows logically that there will be a larger number of users and supporters. The provision of coaccessibility will initially increase awareness; thus, hopefully, larger groups of people will be supporting MA. Families of the disabled who are not aware of options will also be informed. It would not be completely wrong to posit that not every family who has a disabled child in, for example, remote villages in the East of Turkey (that are cut off from the rest of the country especially due to weather conditions during harsh winters) know of the options available for the social inclusion of their child. They would not all be aware of options such as having their child learn a standardized sign language or have the child access audiovisuals with AD. For example, at a conference on the new Turkish MA initiative hosted in Kars (a city on the eastern border of Turkey) at the Kafkas University, the organizers invited the residents of a remote village (for details, see Kars Hakimiyet, 2019). The MA experts were informed that the population of this village were either Deaf or blind due to consanguineous marriages and there was only a single non-disabled person in the village who used TiD and thus served as an interpreter to the whole village in their interactions with the outside world.

A second social benefit of coaccessibility ties in with viewer habits especially in rural settings and even in major cities in a majority of households. In the Turkish setting, 
(excluding the privileged younger generation forming a minority in large cities), Turkish families watch television together, especially at night. It is the cheapest and most widespread form of entertainment. Initial findings in research conducted (Batmaz and Aksoy, 1995) showed a high trend and though in recent years figures are declining, the reality of 'Turkish family television time' still holds true. For example, $86.7 \%$ of the participants in the survey conducted by Radyo ve Televizyon Üst Kurulu (RTÜK) (2018) stated they watched television regularly, whereas only $13.3 \%$ did not watch television. Sixty-four percent of the population watches the media on regular single television sets in homes; $54 \%$ of the population also watch media on computers, $40 \%$ on smart $\mathrm{TV}, 36 \%$ on tabletsized devices, $33 \%$ on desktop computers. The increasing trend of following media on devices other than televisions is more prevalent among the younger generation; whereas the average viewer still prefers the classical television set. On weekdays, $27.3 \%$ of the population, on weekends $23.2 \%$ watch television $2-3$ hours a day; $20.1 \%$ of the population watch television 3-4hours a day; the daily television watching average is 3 hours 34 minutes. The most frequently watched programmes are the news (on an average 24 days a month) and television series (on an average of 15 days a month). Viewers also like to watch a variety of shows, sports and other programmes. Research also reveals that trust in traditional media rates higher (69.2\%) then social media (53.7\%) (RTÜK, 2018). Thus, television unites and brings together families.

Coaccessibility, in this sense, brings together members of the same family and even those with different disabilities. There are multiple reasons for deafness or blindness and the listing of these does not fall within the scope of this study. But, an example of disability figures related to consanguineous marriages may provide a perspective on the figures. Research on children born with disabilities from consanguineous marriages in a survey in two villages in Anatolia revealed that a total of $26 \%$ of the children born of such marriages were $\mathrm{D} / \mathrm{deaf}$ and 19\% were blind (Nar, 2019: 235). These villages are not idiosyncratic but reflective of the Turkish reality in general, thus provide an estimate for the larger population. In a country where consanguineous marriages are common, children born of this union may have disabilities and even differing disabilities (for research on this issue, see Başaran, 1973; Düzcan, 1994; Elibüyük, 1989; Uskun, 2001).

Many researchers have noted that the Deaf children and blind children were generally sent off to boarding school and as a result became disassociated from their families, who they felt 'did not share their world'. Inclusive education began in Turkey in 1983 with Law number 2916 (Özel Eğitime Muhtaç Çocuklar Kanunu); it was further promoted with Decree Law 573 in 1997 (Özel Eğitim Hakkında Kanun Hükmünde Kararname) and the special Directive issued in 2000 (Özel Eğitim Hizmetleri Yönetmeliği (Milli Eğitim Bakanlığı, 2010). Although efforts to build the necessary system increased from 1988 through 1991 (Uysal, 2003), 75 more special private special schools were established between 1992 and 1995 to add to the original 75 established between 1950 and 1992 (Sucuoğlu and Kargın, 2010).

If children and members of families were integrated into the family with common time providing access for all, some things may change. Family living standards for families with disabled members are quite low when compared to other developed countries. Furthermore, social experts underline that instead of the whole family unit (Aysan and Özben, 2007: 1-6), it falls to mostly the mothers to integrate the child or the family 
member into their lives and thus mothers are deprived of doing other activities which would also increase the quality of their lives (Canarslan and Ahmetoğlu, 2015: 19) and the child's/family members life.

Coaccessibility allows a small but common ground for this to change. Laughing and crying at the same images, shared hours doing something together is marked as the most important form of integration for the disabled by social researchers in Turkey. All in all, it is safe to say that coaccessibility has many under-researched social implications.

\section{Conclusion}

According to Jaeger et al. (2017: 58-70), the language of human rights and social justice is employed to express the need for fairness, equality and respect. The achievement of equality, however, is not just a means of finding a way to accomplish equal distribution of resources or opportunities, because different needs and social contexts may require greater interventions for certain groups to achieve equality. Together, these structures form the basis for the protection and fostering of equity in society.

Coaccessibility that is a step to building equal access to media services is on the Turkish agenda because initially accessibility was provided in this manner by major actors (VOD by Kanal D, 2019; TRT, 2019 - see relevant websites for examples) and benefits have been noted by the end-user communities, NGO's and others. But this is not the only reason coaccessibility is on the agenda in Turkey. It is being researched and discussed at present for the simple reason that the technical infrastructure at this point does not allow for other options. It would require resources to realign present infrastructure for additional audial channels, redesigning television screens, changing remotes and maybe even television sets in homes, and so on, to provide optional accessibility. So the bottom line is coaccessibility may be around for a while in the Turkish setting. The other alternative would be the one implemented so far and that is to limit accessibility with either one mode or a limited number of programmes (e.g. SLI on the morning news, SDH on a limited number of programmes) or to provide VOD options only. The problem with the sole provision of VOD versions (though not the focus of this article per se) can be exemplified as it would not lead to the social interaction coaccessibility brings about, and more importantly, financially it would require buying a large Internet services package, a computer or similar device and even training (some) individuals to use it, hence a financial concern. This setting will of course (hopefully) change through time as technology develops. Those concerned with the provision of MA services are invested in upgrading infrastructure, the state supports wide scale initiatives and developments will ensue. But, for the time being, it looks like Turkish audiences will be getting used to coaccessibility.

Informal poles (by no means conclusive evidence) before, during and after the RTÜK process referred to also revealed interesting facts about how the non-disabled view coaccessibility. Whereas it seems like a majority of the people interviewed were open to coaccessibility, other non-disabled viewers saw it as an infringement of their own enjoyment of media. Although, everyone believed that MA should be supported, there were those who felt that the disabled should be served separately from them. Media channels were also afraid of losing non-disabled viewers and screen space and design opportunities. 
The rate and pace of change, when and how MA will be implemented to suit everyone concerned will depend on technology and finances. How far the infrastructure of each channel and platform will permit the optional use of SDH, SLI and AD is still to be seen. At the RTÜK workshop in 2019, only a handful of media representatives stated they had the resources to make accessibility optional. The technical and financial issues need to be resolved before the dust settles on this aspect of the subject.

Today, in Turkey, potential political, social, educational and technical implications of coaccessibility are still being researched. Many other facets may be revealed as it advances. This research is not only important for Turkey but also for other countries with similar realities and ambitions be it in the Middle East, North Africa, Asia, Latin America or others.

It is to be seen for how long issues about disability and coaccessibility will be such hot items on the national agenda. Currently, the politician, the civil servant, the media provider and others want to provide MA, but due to limitations they would prefer to do this at the lowest cost and with the easiest option possible.

Furthermore, research into coaccessibility also has potential in terms of serving the research undertaken for new approaches such as universal design or design for all. There may be something to be learned from coaccessibility that may have implications for such practices. Today, the issue of accessibility is widely studied with many different approaches to accessibility which serves slightly different purposes, though they all share the same overall goal: to provide as effective and usable opportunities as possible for all potential system users, regardless of the challenges the users may face (Persson et al., 2015). For example, the main goal of the design for all movement was that products are designed for an all-encompassing customer base and that a product is made to be usable by the widest possible range of people. This does not, however, automatically imply that there is such a thing as a single solution that suits all. There are several definitions of the term design for all. The European Institute for Design and Disability (EIDD, 2004) has defined design for all as 'design for human diversity, social inclusion and equality', which probably is the most widely spread definition. Design for all, universal access and inclusive design are all different names of approaches that largely focus on increasing the accessibility of the interactive system for the widest possible range of use. The current buzzword in accessibility studies is universal design. Hamraie (2016) states that 'although Universal Design gains popularity as a common sense strategy for crafting built environments for all users, accessibility for disabled people remains a marginal area of inquiry within design practice and theory' (p. 1). In order for universal design to gain ground and the crafting of such design to serve a purpose, not only individual disability groups but a joint effort of all designated disability groups is necessary to draw a framework. Persson et al. (2015) define this as

the extent to which products, systems, services, environments and facilities are able to be used by a population with the widest range of characteristics and capabilities (e.g. physical, cognitive, financial, social and cultural, etc.), to achieve a specified goal in a specified context.

Coaccessibility practices and implementations provide a means to bring these discussions together on a single platform across a variety of services and products and to access 
how each area of disability can be addressed within the larger whole. Users accessing the same product not only understand each other's needs but designers of each aspect of the product understand how their design will fit into the whole. Coaccessibility in this sense also provides a common learning and experience ground for future revelations in universal design and design for all.

In conclusion, audiovisual translation in its largest sense has always been a tool for the manipulation of the society in the Turkish case. Whether it was the inception of the Western image and society through the adaptations of Western films in the earlier examples, or the use of Standard Turkish dubbing techniques for native language learning, or the promotion of subtitles for foreign language education, the persons in power always felt it was a great tool at their disposal with low education and literacy rates and high viewer rates (see Okyayuz, 2017). Today, it falls to researchers and disabled community representatives to understand if coaccessible MA services can also be tools for the development of communities within a society. The research so far seems to indicate that coaccessibility has potential political, social, educational, and other implications and it looks like it is here to stay in the short term. Turkish end-users embrace the current coaccessibility model and would like it to continue. The ideal setting would of course be optional coaccessibility where everyone could financially and technically access all media products. The ultimate goal in accessibility for Turkey will be to have optional SDH, AD and SLI and the actors need to strive to achieve this. Until the day it is replaced with a better option, it falls to academics to research coaccessibility, to learn from it, to evaluate how researchers interested in universal design and similar initiatives and ensuing research in accessibility to media services can benefit from it and more importantly how society at large benefits from it.

\section{Funding}

The author(s) received no financial support for the research, authorship and/or publication of this article.

\section{ORCID iD}

A Şirin Okyayuz (iD https://orcid.org/0000-0003-0376-0358

\section{References}

Akalın ŞH, Oral AZ and Cavkaydar S (2014) Türk Işsaret Dili. Eskişehir: Anadolu Üniversitesi Yayınları.

Akmeşe PP (2016) Türk İşaret Dili (TID) Eğitimi Ve Yüksek Öğretim Programlarında İşaret Dili Dersi. Ahi Evran Üniversitesi Kırşehir Ĕ̈itim Fakültesi Dergisi 17(3): 341-361.

Arık E (2012-2015) Türk İşaret Dili (TID) Kaynakçası. Available at: http://www.enginarik.com/ turkish-sign-language-bibliography (accessed 1 January 2020).

Audiovisual Media Services Directive (AVMSD) (2018) Available at: https://eur-lex.europa.eu/ legal-content/EN/ALL/?uri=CELEX:32010L0013 (accessed 1 January 2020).

Aysan FŞ and Özben (2007) Engelli Çocuğu Olan Anne Babaların Yaşam Kalitelerine İlişkin Değişkenlerin İncelenmesi. Dokuz Eylül Üniversitesi Buca Eğitim Fakültesi Dergisi 22: 1-6. Başaran N (1973) Anadolu'nun Genetik Yapısı Üzerine Çalışmalar III, Diyarbakır ve Çevresinde Yaşayan İnsanlar Arasındaki KanYakını Evlenmeler ve Bunların Mediko-sosyal Yönü. A. $\ddot{U}$. Diyarbakır Tıp Fakültesi Dergisi 2(1): 71-86. 
Batmaz V and Aksoy A (1995) T.C. Başbakanlık Aile Araştırma Kurumu. Türkiye'de Televizyon ve Aile (Elektronik Hane). Available at: https://docplayer.biz.tr/3124748-Turkiye-de-televizyon-ve-aile.html (accessed 15 February 2020).

Beseghi M (2013) Having fun in the classroom: subtitling activities. Language Learning in Higher Education 3(2): 395-407.

Bianchi F (2015) Subtitling science: an efficient task to learn content and language. Lingue $e$ Linguaggi 15: 7-25.

Caimi A (2006) Audiovisual translation and language learning: the promotion of intralingual subtitles. The Journal of Specialised Translation 6: 85-98.

Canarslan H and Ahmetoğlu E (2015) Engelli Çocuğa Sahip Ailelerin Yaşam Kalitesinin İncelenmesi. Trakya Üniversitesi Sosyal Bilimler Dergisi 17(1): 13-31. Available at: https:// dergipark.org.tr/download/article-file/321329

Convention on the Rights of Persons with Disabilities (CRPD) (2006) Available at: https://www. un.org/development/desa/disabilities/convention-on-the-rights-of-persons-with-disabilities. html (accessed 1 January 2020).

Díaz-Cintas J and Fernández Cruz M (2008) Using subtitled video materials for foreign language instruction. In: Díaz Cintas J (ed.) The Didactics of Audiovisual Translation. Amsterdam: John Benjamins Publishing Company, pp. 201-214.

DİE ve Başbakanlık Özürlüler İdaresi Başkanlığı (2002) Özürlüler Araştırması, Başbakanlık Özürlüler İdaresi Başkanlı̆̆l, Yayın No: 43. Ankara: Kalemdar Matbaacılık.

Doğan M (2015) İsitme Engelli Çocuklarda Zeka: Demografik, Eğitimsel ve Odyolojik Özellikle bir Değerlendirme. Eğitim ve Bilim 40(180): 135-154.

Donat C (2011) II. Bölüm-Sizin Haklarınız. Türkiye'de Engelli Gerçeği. İstanbul: Müsaid Cep Kitapları. Available at: https://www.musiad.org.tr/uploads/yayinlar/cep-kitaplari/pdf/30turkiye \%E2\%80\%99de-engelli-gercegi.pdf

Düzcan F (1994) Sivas Populasyonunda Akraba Evliliği Sıklı̆̆l ve Aileler Üzerindeki Tıbbi Etkileri, Cumhuriyet Üniversitesi, Sağllk Bilimleri Enstitüsü, Sivas. Unpublished PhD Thesis.

Elibüyük Z (1989) Hacettepe Üniversitesi Çocuk Hastanesi Genetik Ünitesine Başvuran Hastalarda Akraba Evliliği ve Tıbbi Sonuçlarının Incelenmesi. Hacettepe Üniversitesi Tıp Fakültesi Çocuk Sağlı̆̆l ve Hastalıkları Anabilim Dalı, Uzmanlık Tezi. Unpublished PhD Thesis, Ankara.

Ellis K and Kent M (2011) Disability and New Media. New York; London: Routledge.

Engelliler Hakkında Kanun (2005) Engelliler Hakkında Kanun: Kanun Numaras1: 5378. Available at: http://www.mevzuat.gov.tr/MevzuatMetin/1.5.5378.pdf (accessed 1 January 2020).

Ergin ON (1939) Dilsizler ve körler mektebi: Türk Maarif Tarihi (Vol. 3). İstanbul: Osmanbey Matbaası, pp. 1165-1172.

European Regulators Group for Audiovisual Media Services (ERGA) (2014) Available at: https:// ec.europa.eu/digital-single-market/en/audiovisual-regulators (accessed 1 January 2020).

Fırat B (2019) 'Medya ürünlerinde işaret dili çevirmenliği'. Yayımlanmamış bildiri. In: Kafkas Universitesi 6. Çeviri Seminerleri, Kars, 4 August.

Gök S (1958) Dünyada ve Türkiye'de Sağır, Dilsiz Okulları Tarihçesi ve Eğitim Sistemi. Türkiye Sağır, Dilsiz ve Körler Tesanüt Cemiyeti Neşriyatı. Sayı 1. İstanbul: Hüsnütabiat Matbaası.

Hamraie A (2016) Universal design and the problem of 'post-disability' ideology. Design and Culture 83: 285-309.

Jaeger PT, Wentz B and Bertot JC (2017) The intersection of human rights, social justice, the Internet, and accessibility in libraries: access, education, and inclusion. In: Lazar $\mathrm{J}$ and Stein MA (eds) Disability, Human Rights, and Information Technology. Philadelphia, PA: University of Pennsylvania Press, pp. 58-70. 
Kanal D (2019) Available at: http://engelsiz.kanald.com.tr/

Kars Hakimiyet (2019) KAÜ'de 6. Çeviri semineri gerçekleşti. Kaynak: KAÜ'de 6. Çeviri semineri gerçekleşti. Available at: http://www.karshakimiyet.com/kaude-6-ceviri-semineri-gerceklesti-3092h.htm (accessed 1 January 2020).

Kobal HŞ and Şenturan Ş (1995) İşaret Dili Alfabesi. Ankara: Odak Ofset Matbaacılık.

Lazar J and Stein MA (2017) Introduction. In: Lazar J and Stein MA (eds) Disability, Human Rights, and Information Technology. Philadelphia, PA: University of Pennsylvania Press, pp. 1-8.

Matamala A and Orero P (2018) Standardising accessibility: transferring knowledge to society. Journal of Audiovisual Translation 1(1): 139-154.

Media for All (2019) M4A8 - 8th media for all international conference. Available at: https:// www.tolk.su.se/english/media-for-all-8 (accessed 1 January 2020).

Milli Eğitim Bakanlığı (2010) İlköğretim Okullarındaki Kaynaştırma Uygulamalarının Değerlendirilmesi. Ankara: Milli Eğitim Basımevi.

Mitterer H and Mcqueen JM (2009) Foreign subtitles help but native-language subtitles harm foreign speech perception. PLOS ONE 4(11): e7785.

Nar MŞ (2019) Tibbi Antropoloji: Akraba Evliliklerinin Patolojik Etkileri. Available at: http:// dergiler.ankara.edu.tr/dergiler/26/1668/17804.pdf (accessed 1 January 2020).

Okyayuz AŞ (2017) Power, society and AVT in Turkey. In: Deckert M (ed.) Audiovisual Translation Research and Use. New York; Berlin: Peter Lang Edition, pp. 115-134.

Okyayuz AŞ, Fırat, B, Oral, Z (2017) Sağırların ayrıntılı altyazı ve işaret dili çevirisiyle görselişitsel ürünlere erişimine iliş̧kin anket çalışmast. Unpublished Survey.

Öztürk M (2011) Türkiye'de Engelli Gerçeği. İstanbul: Müsiad Cep Kitapları, Ajansvista Matbaacilik.

Parlak S (2011) Türkiye'de İşitme Engelliliği ve Işsletmelerdeki Danışmanlık Hizmetleri Üzerine Pilot Araştırma. Bursa: Ekin Yayınevi.

Pavesi M and Perego E (2008) Tailor-made interlingual subtitling as a means to enhance second language acquisition. In: Díaz Cintas J (ed.) The Didactics of Audiovisual Translation. Amsterdam: John Benjamins Publishing Company, pp. 215-226.

Persson H, Åhman H, Yngling AA, et al. (2015) Universal design, inclusive design, accessible design, design for all: different concepts - one goal? On the concept of accessibility - historical, methodological and philosophical aspects. Universal Access in the Information Society 14: 505-526.

Radyo ve Televizyon Üst Kurulu (RTÜK) (2018) Televizyon İzleme Eğilimleri Araştırması. Available at: https://www.rtuk.gov.tr/assets/Icerik/AltSiteler/televizyonizlemeegilimleriarastirmasi2018.pdf

Radyo ve Televizyon Üst Kurulu (RTÜK) (2019) Sağırların, işitme ve görme engellilerin görselişitsel medya hizmetlerine erişiminin iyileştirilmesi çalıştayı. Available at: https://www.rtuk. gov.tr/assets/Galeri/Haberler/sagirlarin-isitme-ve-gorme-engellilerin-gorsel-isitsel-medyahizmetlerine-erisiminin-iyilestirilmesi-calistayi-sonuc-bildirisi.pdf

Resmî Gazete (2009) Sayı: 27288. Milletlerarası Sözleşme Karar Sayısı: 2009/15137-3/12/2008 tarihli ve 5825 sayll Kanunla onaylanması uygun bulunan ekli 'Engellilerin Haklarına İlişkin Sözleşme'nin onaylanması. Available at: http://www.resmigazete.gov.tr/eskiler/2009 /07/20090714-1.htm (accessed 1 January 2020).

Resmî Gazete (2019) Sağırların, İşitme ve Görme Engellilerin Yayın Hizmetlerine Erişiminin Iyileştirilmesine İlişkin Usul ve Esaslar Hakkında Yönetmelik. Available at: https://www. resmigazete.gov.tr/eskiler/2019/10/20191011-15.htm (accessed 11 October 2019).

Sarıkaya B and Börekçi M (2016) Iş̧itme Engelli Öğrencilerin Eğitiminde Yaşanan Sorunlar ve Çözüm Önerileri: Erzurum İli Örneği. EKEV Akademi Dergisi 66: 177-194. 
Sart H, Barış S, Sarış1k Y, et al. (2016) Engeli olan çocukların Türkiye'de eğitime erişimi: Durum analizi ve öneriler. Eğitim Reformu Girişimi. Available at: http://www.egitimreformugirisimi.org/wp-content/uploads/2017/03/ERG_Engeli-Olan-\%C3\%87ocuklar\%C4\%B1nT\%C3\%BCrkiyede-E\%C4\%9Fitime-Eri\%C5\%9Fimi.pdf (accessed 1 January 2020).

Sesli Betimleme Derneği (SEBEDER) (2018) Hakkımızda. Available at: http://sebeder.org/hakkimizda.php (accessed 3 January 2019).

Soysal Ş, Koçkar Aİ, Erdoğan E, et al. (2001) Öğrenme güçlüğü olan bir grup hastanın WISC-R profillerinin Incelenmesi. Klinik Psikiyatri 4: 225-231.

Sucuoğlu B and Kargın T (2010) İlköğretimde Kaynaştırma Uygulamaları. Ankara: Kök Yayınevi. Taylor C (2003) Multimodal transcription in the analysis: translation and subtitling of Italian films. The Translator 9(2): 191-205.

The EIDD Stockholm Declaration 2004 (2004) Available at: http://dfaeurope.eu/what-is-dfa/dfadocuments/the-eidd-stockholm-declaration-2004/ (accessed 1 January 2020).

TRT (2019) Available at: http://engelsiztrt.tv/ (accessed 3 January 2019).

TÜİK and ASPB (2010) Özürlülerin sorun ve beklentileri araştırmast. Available at: https:// kutuphane.tuik.gov.tr/pdf/0014899.pdf (accessed 1 January 2020).

Turgut K and Taşçı SS (2011) Türkiye'de İlk İşitme Engelli Okulları, Eğitim Yöntemleri ve İşitme Engelliliğe Tarihsel Bir Bakış, 1889-1960. Available at: https://docplayer.biz.tr/31180691Turkiye-de-ilk-isitme-engelli-okullari-egitim-yontemleri-ve-isitme-engellilige-tarihsel-birbakis.html (accessed 15 February 2020).

Understanding Quality in Media Accessibility (UMAQ) (2018) The UMAQ project, the UMAQ conference. Available at: http://pagines.uab.cat/umaq/umaq-conference (accessed 1 January 2020).

UNICEF (2012) The Right of Children with Disabilities to Education: A Rights-Based Approach to Inclusive Education, Position Paper. Geneva: UNICEF.

Uskun E (2001) Akraba Evlilikleri. Sürekli Tip Eğitim Dergisi 10(2): 54-56.

Utsukarcı O and Özdemir D (2019) Sağırlar konfederasyonu'nun sağırların eğitimi konusunda araştırma ve öneriler raporu Ocak 2019. Unpublished report, Submitted to the Ministry of National Education, Ankara.

Uysal A (2003) Kaynaştırma Uygulaması Yapan Öğretmenlerin Kaynaştırmaya İlişskin Görüşleri. 13. Ulusal Ĕ̈itim Kongresi. Ankara: Kök Yayınevi.

Uysal A (2010) Işsitme Engellilerde Türkçe Öğretimi, Sorunlar, Öneriler. Unpublished Thesis, Yüksek Lisans Tezi, İstanbul Üniversitesi Sosyal Bilimler Enstitüsü, İstanbul.

Vanderplank R (1988) The value of teletext subtitling in language learning. ELT Journal 42: $272-281$.

Williams $\mathrm{H}$ and Thorn $\mathrm{H}$ (2000) The value of teletext subtitling as a medium for language learning. System 28: 217-228.

Yıldırım N (1997) İstanbul'da Să̆ır-Dilsiz ve Âmâların Ĕ̆itimi. İstanbul Armağanı c.3. İstanbul: Büyükşehir Belediyesi Yayınları, Erkam Matbaası, pp. 305-330.

Yükseköğretim Kurulu Engelli Erişim Komisyonu (2019) Hakkımızda. Available at: https://engelsiz.yok.gov.tr/ana-sayfa (accessed 1 January 2020).

Yükseköğretim Kurumları Engelliler Danışma ve Koordinasyon Yönetmeliği (2010) Resmî Gazete Tarihi: 14.08.2010 Resmî Gazete Sayısi: 27672. Available at: http://www.mevzuat.gov.tr /Metin.Aspx?MevzuatKod=7.5.14214\&MevzuatIliski=0\&sourceXmlSearch $=\mathrm{Y} \% \mathrm{C} 3 \% \mathrm{~B}$ Cksek\%C3\%B6\%C4\%9Fretim\%20Kurumlar\%C4\%B1\%20\%C3\%96z\%C3\%BCr1\%C3\% BCler\%20Dan\%C4\%B1\%C5\%9Fma\%20ve\%20Koordinasyon\%20Y\%C3\%B6netmeli\% C4\%9Fi (accessed 1 January 2020).

Zarei AA and Rashvand Z (2011) The effect of interlingual and intralingual, verbatim and nonverbatim subtitles on L2 vocabulary comprehension and production. Journal of Language Teaching Research 2(3): 618-625. 